\title{
Ekuitas Merek Berbasis Pelanggan
}

\author{
Nur Laily Hawa E \\ STIE Indocakti Malang, Indonesia \\ e-mail: nurlaily.hawa@gmail.com
}

\begin{tabular}{|c|c|}
\hline \multicolumn{2}{|l|}{ Article Info: } \\
\hline Receive & Mei 2020 \\
\hline Revised & : Juni 2020 \\
\hline Accepted & : Juni 2020 \\
\hline Published & : Juli 2020 \\
\hline DOI & : 10.21067/mbr.v4i1.4665 \\
\hline Copyright & $\begin{array}{l}\text { : Management and } \\
\text { Business Review }\end{array}$ \\
\hline
\end{tabular}

Keywords:

brand equity, customer purchase, decision making process

\begin{abstract}
The purpose of this study was to determine the assessment of respondents and to determine the process of decision making at STIE Indocakti Malang and to determine the effect of brand equity on student decisions at STIE Indocakti Malang. This research is descriptive research and verification research. Data were collected by observation, interview and questionnaire techniques and tested for validity and reliability. Data were analyzed using Structural Equation Modeling analysis. The results of this study indicate that STIE Indocakti Malang brand equity is included in the high category and also for purchasing decision making is also included in the high category. STIE Indocakti Malang brand equity has a positive and significant influence on the consumer purchasing decision process.
\end{abstract}

Abstrak: Tujuan penelitian ini adalah untuk mengetahui penilaian responden dan untuk mengetahui proses pengambilan keputusan kuliah di STIE Indocakti Malang serta untuk mengetahui pengaruh ekuitas merek terhadap keputusan mahasiswa kuliah di STIE Indocakti Malang. Penelitian ini adalah penelitian deskriptif dan penelitian verifikatif. Data dikumpulkan dengan teknik observasi, wawancara dan kuesioner dan di uji validitas dan reliabilitasnya. Data dianalisis dengan menggunakan analisis Structural Equation Modeling. Hasil penelitian ini menunjukkan bahwa ekuitas merek STIE Indocakti Malang termasuk kategori tinggi dan juga untuk pengambilan keputusan pembelian juga termasuk kategori tinggi. Ekuitas merek STIE Indocakti Malang memiliki pengaruh positif dan signifikan terhadap proses keputusan pembelian konsumen. 


\section{Pendahuluan}

Merek menjadi sangat strategis bagi perusahaan, karena efektivitas pengelolaan merek bermanfaat untuk mempertahankan kesetiaan konsumen, membantu memfokuskan program pemasaran perusahaan, citra perusahaan dapat terbangun, dan dapat mempermudah prosedur klaim apabila terdapat cacat produksi pada produk yang dibeli oleh konsumen. Seorang pemasar harus memiliki keterampilan khusus untuk menciptakan nilai, mempertahankan, dan melindungi nilai bagi merek. Hal ini penting karena konsumen akan memandang penting arti sebuah merek sebagai bagian penting dari suatu produk. Merek membantu pembeli dalam berbagai cara. Merek membantu konsumen dalam mengenal dan mengidentifikasi produk-produk yang sesuai dengan selera dan kebutuhan mereka yang akhirnya memuaskan apa yang mereka inginkan. Bahkan merek memberitahu kepada konsumen mengenai kualitas produk itu sendiri. Seorang pembeli yang membeli merek yang sama akan mengetahui bahwa ia akan mendapatkan fitur, manfaat, dan kualitas yang sama dari produk yang sama yang telah dibelinya tiap kali ia membeli merek tersebut.

Memposisikan suatu merek pada bidang jasa memerlukan suatu asosiasi dari komponen-komponen tangible (berujud) misalnya sosok seseorang yang menciptakan jasa atau hal-hal yang berhubungan dengan jasa yang ditawarkan. Hal ini dikarenakan jasa merupakan produk tak berujud. Begitu pentingnya membangun merek menyebabkan persoalan merek ini bukan lagi persoalan manajer pemasaran semata. Merek adalah menjadi tanggungjawab CEO, karena kesalahan keputusan terhadap merek (branding) akan menyebabkan hancurnya nilai perusahaan, namun apabila mampu mengambil keputusan yang tepat tentang merek (branding) tentu akan tercapai peningkatan ekuitas merek, dampaknya adalah peningkatan kinerja perusahaan dan mampu menghadapi persaingan.

Ekuitas merek adalah nilai tambah yang diberikan pada produk dan jasa. Nilai akan tercermin dari cara konsumen merasakan, berpikir, dan bertindak terhadap suatu merek. Ekuitas merek merupakan seperangkat asset dan liabilitas yang berkaitan baik dengan nama, merek, maupun simbolnya (Aaker, 2015). Ekuitas merek bisa mengurangi atau menambah nilai yang diberikan oleh suatu barang atau jasa kepada perusahaan. Definisi tersebut memperlihatkan bahwa merek dapat menyebabkan efek baik positif maupun negatif. Jadi dapat disimpulkan bahwa merek tidak sekedar sebuah nama, simbol atau bentuk-bentuk tangible saja, melainkan gabungan dengan bentuk-bentuk intangible lain seperti awareness, reputasi dan lain-lain yang dimiliki perusahaan yang membedakan dengan produk perusahaan lain. Ekuitas merek berbasis pelanggan merupakan perbedaan tanggapan konsumen terhadap merek sebagai akibat dari perbedaan akan pengetahuan merek. 
Pada saat suatu merek teridentifikasi, dan reaksi konsumen lebih positif terhadap produk, maka dapat dikatakan euitas merek berbasis pelanggan adalah positif. Terdapat tiga hal penting ekuitas merek berbasis pelanggan akan muncul, yaitu: perbedaan respon konsumen, perbedaan pengetahuan konsumen tentang merek, dan perbedaan respon konsumen yang membentuk ekuitas merek, dan akan tercermin pada persepsi dari konsumen, preferensinya, dan perilakunya yang berhubungan dengan pemasaran merek. Suatu merek yang lebih kuat akan menciptakan pendapatan yang lebih besar.

Tantangan pemasar dalam membangun kekuatan merek adalah memastikan pelanggan memiliki pengalaman yang tepat tentang suatu produk atau jasa, serta program pemasaran dalam rangka menciptakan pengetahuan merek yang diinginkan. Sumber dari ekuitas merek adalah persepsi konsumen (Keller \& Lehmann, 2006), maka penting bagi perusahaan untuk dapat mengukur ekuitas merek berdasarkan perspektif konsumen. Ekuitas merek berdasarkan konsumen menurut Keller merupakan perbedaan pengaruh dari pengetahuan merek pada respon konsumen terhadap pemasaran merek.

Penelitian tentang ekuitas merek telah banyak dilakukan di luar negeri maupun di Indonesia. Penelitian-penelitian tersebut secara langsung maupun tidak langsung mengungkapkan bahwa ekuitas merek berpengaruh positif terhadap keputusan konsumen untuk menggunakan suatu produk (Pinassang \& Rahardjo, 2017; Suharyani et al., 2016). Ekuitas merek akan mempengaruhi persepsi terhadap kualitas, yang selanjutnya akan mempengaruhi loyalitas (Sari, 2017). Hasil penelitian Berry (2000) melakukan perusahaan jasa yang memiliki kinerja yang tinggi, menemukan bahwa brand equity yang positif akan menciptakan keuntungan dan meningkatkan kepercayaan konsumen akan produk jasa yang sifatnya invisible serta membantu meningkatkan pemahaman konsumen dan mampu memvisualisasikan apa yang mereka beli. Aktivitas komunikasi eksternal menjadi penting untuk membangun suatu merek, selain kemampuan menghadirkan pengalaman yang menyenangkan saat konsumen menikmati jasa layanan.

Konsumen akan mempunyai banyak pilihan karena banyaknya merek-merek yang tersedia di pasar. Kondisi tersebut menutntu perusahaan untuk memahami perilaku konsumen sebagai proses dimana konsumen membuat keputusan pembelian dalam rangka menentukan barang atau jasa yang dibeli (Lamb et al., 2011). Studi mengenai perilaku konsumen juga meliputi analisis faktor-faktor yang mempengaruhi keputusan membeli dan penggunaan produk. Yang terpenting bahwa dalam membuat keputusan, konsumen memiliki tujuan yang harus dipenuhi atau dipuaskan.

Hubungan ekuitas merek dengan proses keputusan dinyatakan oleh Aaker (2015) "brand equity can also affect the customer's confidence in the purchase decision; and brand equity assets, particularly perceived quality and brand associations, provide value to 
the customer is by enhancing the customer's satisfaction when the individual uses the product". Jadi jelas bahwa ekuitas merek mempengaruhi kepercayaan diri konsumen dalam keputusan pembelian (Wiastuti \& Kimberlee, 2018; Widhiarta \& Wardana, 2015). Pada perusahaan jasa yang bersifat intangible, ekuitas merek yang kuat menjadi penting untuk meningkatkan kepercayaan konsumen dalam menggunakan jasa tersebut (Berry, 2000; Widhiarta \& Wardana, 2015). Konsumen akan mempertimbangkan ekuitas merek yang kuat dalam melakukan pembelian, dan ada usaha yang kuat untuk mencoba suatu merek baru, apalagi menghadapi merek baru yang bermunculan setiap tahunnya (Davis, 2000). Penelitian hubungan ekuitas merek dengan keputusan memilih universitas meunjukkan bahwa ekuitas merek mempengaruhi minat memilih tempat kuliah (Harwani, 2017; Nuryadin et al., 2019; Rido et al., 2019). Melalui penelitian ini akan ditelaah lebih jauh tentang pengaruh ekuitas merek terhadap proses keputusan pembelian/pemilihan mahasiswa kuliah di STIE Indocakti Malang.

\section{Metode}

Tujuan penelitian adalah untuk mengetahui keputusan pembelian konsumen dan pengaruh ekuitas merek terhadap proses keputusan mahasiswa kuliah di STIE Indocakti Malang. Penelitian menggunakan dua jenis pendekatan yaitu penelitian desekriptif dan penelitian verifikatif. Penelitian deskriptif adalah bertujuan memperoleh gambaran keadaan fenomena variabel yaitu ekuitas merek dan proses keputusan pembelian konsumen. Penelitian verifikatif untuk menguji kebenaran hipotesis.

Variabel bebas ekuitas merek diukur dengan indikator kesadaran merek (X1), asosiasi merek (X2), persepsi kualitas (X3) dan loyalitas merek (X4). Sedangkan variabel terikat adalah Proses Keputusan Konsumen. Populasi dalam penelitian ini adalah seluruh mahasiswa STIE Indocakti Malang, dan menggunakan sampel sebanyak 100 mahasiswa yang diambil secara random. Pengumpulan data dilaksanakan dengan observasi, wawancara dan pemberian kuesioner serta studi kepustakaan.

Kuesioner dilakukan pengujian validitas dan reliabilitas, pengujian validitas menggunakan teknik korelasi Product Moment Pearson, sedangkan pengujian reliabilitas dengan metode Cronbach Alfa. Pengujian validitas setiap instrumen dihitung dengan menggunakan rumus korelasi Product Moment Pearson antara skor item dengan total skor item yang telah dikoreksi. Hasil perhitungan dari validitas untuk pernyataan dalam variabel ekuitas merek dan proses keputusan pembelian menunjukan bahwa semua pernyataan kuesioner dapat dinyatakan valid karena koefisien validitasnya sama dengan atau lebih dari 0,3. Selanjutnya hasil uji reliabilitas yang dilakukan terhadap semua item dalam penelitian ini menunjukan bahwa semua item penelitian dapat dikatakan reliabel karena koefisien 
reliabilitasnya lebih dari 0,7. Teknik analisis data untuk pengujian hipotesis menggunakan Structural Equation Modelling, dengan bantuan program LISREL 8.3.

\section{Hasil}

\section{Analisis Deskriptif}

Untuk mengetahui bagaimana kondisi ekuitas merek dari STIE Indocakti Malang, maka digunakan kuesioner pilihan ganda dan juga pertanyaan terbuka. Berdasarkan hasil analisis data, variabel ekuitas merek yang terdiri dari sub variabel kesadaran merek, asosiasi merek, kesan kualitas dan loyalitas merek berada dalam kategori tinggi. Walaupun demikian pada sub variabel kesan kualitas masih banyak yang menjawab cukup dan untuk pertanyaan fasilitas yang dimiliki menjawab baik, sedangkan untuk loyalitas merek, masih banyak responden (sekitar 60\%) yang mempertimbangkan untuk kuliah di tempat lain. Untuk kondisi proses keputusan mahasiswa kuliah di STIE Indocakti digunakan pula kueisoner dengan menggunakan pertanyaan pilihan ganda. Dari hasil pengolahan data, menujukkan bahwa variabel proses keputusan pembelian konsumen yang terdiri dari sub variabel pengenalan kebutuhan, pencarian informasi, evaluasi alternatif, keputusan pembelian dan perilaku pascapembelian berada dalam kategori tinggi.

\section{Model Pengukuran}

Seperti yang telah dijelaskan bahwa model struktural terdiri dari dua model yaitu model pengukuran dan model struktural. Analisis model pengukuran ini berguna untuk menunjukkan bagaimana tingkat validitas dan reliabilitas dari indikator-indikator penelitian dalam mengukur konstruknya atau variabelnya dengan kata lain model ini menggambarkan seberapa besar indikator dalam model mampu menjelaskan konstruk atau variabel latennya. Analisis model ini disebut dengan Confirmatory Factor Analysis (CFA). Dalam penelitian ini terdapat empat indikator untuk ekuitas merek dan lima indikator untuk proses keputusan pembelian.

Hasil perhitungan secara lengkap dari program Lisrel 8.5 menunjukkan bawah: hasil pengujian reliabilitas konstruk untuk variabel ekuitas merek menghasilkan nilai sebesar 0,7792 lebih besar dari nilai kritisnya yaitu 0,700. Ini menunjukkan bahwa indikator-indikator dari ekuitas merek memiliki tingkat keandalan yang tinggi dalam mengukur variabel ekuitas merek. Dengan menghitung variance extracted juga dapat dijelaskan secara menyeluruh indikatorindikator ekuitas merek mampu menjelaskan variansi ekuitas merek sampai sebesar $47,21 \%$. Sedangkan sisanya sebesar 52,79\% dijelaskan oleh indikator lain yang tidak dimasukkan dalam penelitian ini. Dengan besaran ini dapat disimpulkan indikatorindikator ini secara menyeluruh sudah cukup baik dalam mengukur ekuitas merek. 


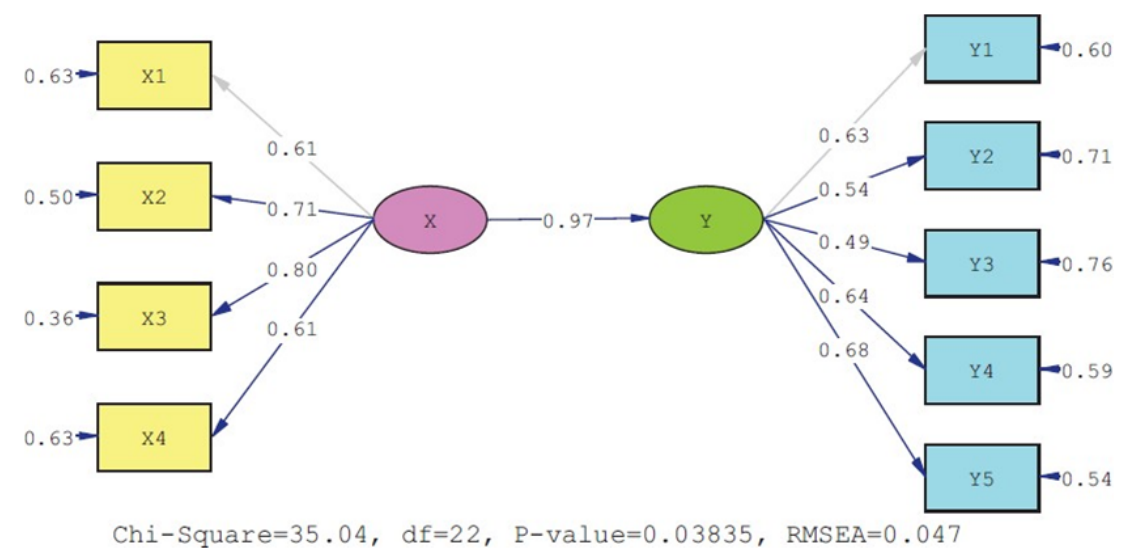

Gambar 1. Measurement Model

Hasil pengujian reliabilitas konstruk menghasilkan nilai sebesar 0,7351 lebih besar dari nilai kritisnya yaitu 0,700. Ini menunjukkan bahwa indikator-indikator dari proses keputusan pembelian konsumen memiliki tingkat keandalan yang tinggi dalam mengukur variabel proses keputusan pembelian konsumen. Dengan menghitung variance extracted juga dapat dijelaskan secara menyeluruh indikatorindikator proses keputusan pembelian konsumen mampu menjelaskan variansi proses keputusan pembelian konsumen sampai sebesar 36,01\%. Sedangkan sisanya sebesar $63,9 \%$ dijelaskan oleh indikator lain yang tidak dimasukkan dalam penelitian ini. Dengan besaran ini dapat disimpulkan indikator-indikator ini secara menyeluruh sudah cukup baik dalam mengukur proses keputusan pembelian konsumen.

\section{Model Struktural}

Seperti yang telah dijelaskan sebelumnya, bahwa dalam analisis SEM tidak hanya membangun model pengukuran namun juga dapat dibangun model struktural yang bertujuan untuk melihat bagaimana pengaruh dari variabel eksogen terhadap variabel endogen. Dalam penelitian ini model structural yang dibangun ini akan memberikan jawaban atas hipotesis penelitian bahwa ada pengaruh signifikan dari ekuitas merek terhadap proses keputusan pembelian mahasiswa STIE Indocakti Malang Hasil perhitungan model structural ditunjukkan pada gambar 2.

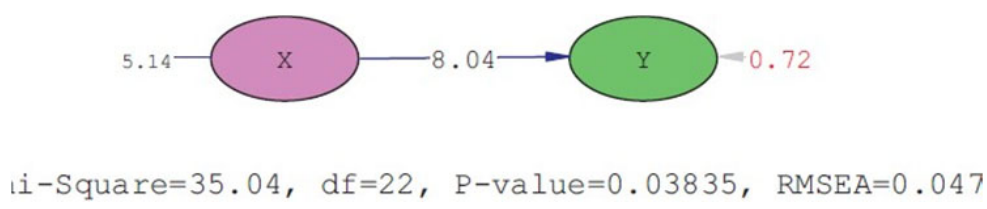

Gambar 2. Model Struktural (t value) 


\section{Pengujian Hipotesis}

Dari hasil perhitungan dengan program LISREL 8.50 untuk pengujian kecocokan model ini diperoleh nilai p-value (0.03835) lebih besar dibandingkan dengan 0,01 sehingga dapat disimpulkan model konseptual yang diajukan oleh peneliti sesuai atau cocok dengan data sehingga hasil penelitian ini dapat dipertangungjawabkan kebenarannya. Selain dilihat dari nilai p-valuenya, untuk menguji kecocokan model dengan data juga dapat dilakukan secara deskriptif dengan melihat nilai goodness of fit index (GFI). Semakin besar nilai GFI maka semakin cocok model dengan data. Model dikatakan fit dengan data jika nilai GFI lebih besar dari 0,90. Dari hasil perhitungan dengan hasil yang terlampir dalam output LISREL diperoleh nilai GFI sebesar 0,97 sehingga dapat disimpulkan model cocok dengan data. Model cocok dengan data mencerminkan bahwa model yang dibangun mencerminkan fenomena yang sebenarnya dalam artian bahwa ekuitas merek memiliki keterkaitan dengan proses keputusan pembelian konsumen.

Dari tabel $t$ student pada tingkat signifikansi sebesar $5 \%$ dan diperoleh nilai $\mathrm{t}$ tabel 1,645. Sedangkan dari hasil perhitungan diperoleh nilai t hitung sebesar 8,04. Terlihat dengan jelas nilai $t$ hitung lebih besar dari $t$ tabel, sehingga dapat disimpulkan bahwa ada pengaruh positif dan signifikan dari ekuitas merek terhadap proses keputusan Mahasiswa kuluah di STIE Indocakti Malang.

Tabel. 1 Rangkuman Analisis Pengaruh Ekuitas Merek Terhadap Proses

Keputusan Pembelian

\begin{tabular}{llll}
\hline & $\begin{array}{c}\text { Koefisien } \\
\text { Jalur }\end{array}$ & $\mathrm{R}^{2}$ & t value \\
\hline $\begin{array}{l}\text { Ekuitas merek terhadap proses } \\
\text { keputusan pembelian konsumen }\end{array}$ & 0,974 & 0,950 & 8.04 \\
\hline
\end{tabular}

Sumber: Output Lisrel 8.50

Terlihat dari tabel 1, ekuitas merek memiliki koefisien jalur sebesar 0,974 dan dengan koefisien determinasi (R2) sebesar 95,0\%. Ini menunjukkan bahwa sebesar 95\% variansi dari proses keputusan Mahasiswa kuliah di STIE Indocakti Malang dipengaruh oleh ekuitas merek STIE Indocakti Malang. Sedangkan sisanya sebesar $5 \%$ dipengaruhi oleh variabel lain seperti kegiatan bauran promosi. Hal tersebut menunjukkan bahwa ekuitas merek STIE Indocakti Malang mempunyai pengaruh yang sangat kuat terhadap proses keputusan pembelian konsumen. 


\section{Pembahasan}

Hasil analisis menunjukkan bahwa ekuitas merek berpengaruh terhadap Proses Keputusan Mahasiswa kuliah di STIE Indocakti Malang, hal ini mendukung beberapa penelitian sebelumnya bahwa ekuitas merek akan mempengaruhi keputusan untuk memilih perguruan tinggi (Harwani, 2017; Nuryadin et al., 2019; Rido et al., 2019). Hal ini bisa dijelaskan bahwa ekuitas merek mempengaruhi kepercayaan diri konsumen dalam keputusan pembelian (Wiastuti \& Kimberlee, 2018; Widhiarta \& Wardana, 2015), dalam hal ini memilih tempat untuk kuliah di perguruan tinggi.

Berdasarkan hasil pemaparan sebelumnya, dominasi proses mahasiswa memilih untuk kuliah di STIE Indocakti Malang karena ekuitas mereknya. Hal tersebut sangat beralasan karena elemen-elemen dalam ekuitas merek tersebut merupakan faktor yang selama ini menjadi perhatian konsumen ketika akan melakukan pembelian. Mengenai pengaruh positif dari ekuitas merek tehadap proses keputusan pembelian mahasiswa untuk kuliah di STIE Indocakti Malang berarti semakin baik kondisi ekuitas merek STIE Indocakti Malang maka akan semakin tinggi proses keputusan untuk kuliah di STIE Indocakti Malang. Dari hal tersebut dapat disimpulkan bahwa untuk menarik konsumen agar memutuskan menjadi mahasiswa di STIE Indocakti Malang maka pihak STIE Indocakti Malang sudah seharusnya meningkatkan ekuitas mereknya dengan mengelola indikator- indikator yang terdapat dalam ekuitas merek tersebut.

Secara berurutan indikator yang paling dapat menjelaskan ekuitas merek adalah kesan kualitas, asosiasi merek, kesadaran merek dan loyalitas merek memiliki nilai yang sama. Hal tersebut menjelaskan bahwa indikator kesan kualitas menjadi indikator yang paling dominan dalam menjelaskan ekuitas merek seperti yang dikatakan Aaker (2015) yang menyatakan bahwa Perceived quality mempunyai peranan yang penting dalam membangun sebuah merek dan menjadi bahan pertimbangan utama bagi konsumen dalam memilih merek dan juga, point pertama untuk menciptakan ekuitas merek dimulai dari kualitas produk atau jasa agar perusahaan menciptakan evaluasi yang positif dari konsumen agar memilih merek, dimana pada umumnya responden akan menilai kekuatan merek STIE Indocakti Malang tinggi setelah mengetahui kinerja kualitas jasa yang dirasakan. Indikator yang dominan kedua adalah asosiasi merek. Faktor kualitas pelayanan menjadi salah satu yang perlu dipertimbangkan oleh STIE Indocakti, selain itu STIE Indocakti juga harus mengedepankan profesionalisme dari suatu sistem pembelajaran serta kualitas pelayanan yang diterima konsumen.

Sedangkan untuk proses keputusan pembelian konsumen, secara berurutan indikator yang paling dapat menjelaskan proses keputusan pembelian konsumen adalah perilaku pasca pembelian, keputusan pembelian, pengenalan kebutuhan, pencarian informasi, dan evaluasi alternatif. Hal tersebut menjelaskan bahwa 
indikator perilaku pasca pembelian menjadi indikator yang paling dominan dalam menjelaskan proses keputusan pembelian konsumen, dimana dalam indikator ini terdapat kepuasan dan ketidakpuasan yang akan menentukan tindakan selanjutnya bagi konsumen untuk kemungkinan lebih tinggi untuk membeli kembali produk tersebut atau merekomendasikan kepada teman-temannya apabila dia puas.

\section{Simpulan}

Berdasarkan pembahasan sebelumnya, maka kesimpulan penting dalam penelitian ini adalah: ekuitas merek, yang tinggi yang dinilai dari sub variabel: kesadaran merek (brand awareness) yang tinggi, asosiasi merek (brand association) yang tinggi. Untuk kesan kualitas (perceived quality) yang tinggi, masih banyak responden yang menjawab cukup untuk kategori fasilitas yang dimiliki Sedangkan loyalitas merek (brand loyalty) STIE Indocakti Malang dinilai tinggi, ini bisa dilihat dari cukup banyaknya mahasiswa yang merekomendasikan STIE Indocakti untuk rekan atau family. Kategori keinginan memilih pendidikan (kuliah) selain di STIE Indocakti Malang berada pada kategori sedang bahkan banyak yang menyatakan setuju dan ini dibuktikan dengan sikap mahasiswa akan mencari alternatif perguruan tinggi lainnya, atau sekedar mencari informasi.

Proses keputusan pembelian konsumen untuk memilih STIE Indocakti Malang sebagai melanjutkan jenjang di perguruan tinggi dinilai tinggi, ini tercermin pada setiap sub variabelnya yaitu pengenalan kebutuhan, pencarian informasi, evaluasi altenatif, keputusan pembelian dan perilaku pascapembelian yang semuanya masuk dalam kategori tinggi.

Hasil pengujian hipotesis menunjukkan bahwa ekuitas merek STIE Indocakti Malang memiliki pengaruh positif dan signifikan terhadap proses keputusan pembelian konsumen. Pengaruh positif tersebut dapat diartikan bahwa semakin baik kondisi ekuitas merek STIE Indocakti Malang, maka akan memperbesar proses keputusan konsumen untuk memilih kuliah di STIE Indocakti Malang.

\section{Daftar Pustaka}

Aaker, D. (2015). Aaker On Branding: 20 Prinsip Esensial Mengelola dan Mengembangkan Brand (edisi terjemahan). PT Gramedia Pustaka Utama.

Berry, L. L. (2000). Cultivating service brand equity. Journal of the Academy of Marketing Science, 28(1), 128-137.

Davis, S. M. (2000). Brand asset management. Driving Profitable Growth through Your Brands. San Francisco. 
Harwani, Y. (2017). Memahami Peran Ekuitas Merek Sebagai Keunggulan Bersaing Terhadap Pengambilan Keputusan dalam Pemilihan Perguruan Tinggi. Jurnal Manajemen, 21(3), 398-417.

Keller, K. L., \& Lehmann, D. R. (2006). Brands and branding: Research findings and future priorities. Marketing Science, 25(6), 740-759.

Lamb, C. W., Hair, J. F., \& McDaniel, C. (2011). Essentials of marketing. Cengage Learning.

Nuryadin, M. T., Yunida, R., \& Padli, P. (2019). Pengaruh Ekuitas Merek terhadap Keputusan Mahasiswa dalam Memilih Kuliah di Politeknik Negeri Banjarmasin. Inovbiz: Jurnal Inovasi Bisnis, 7(2), 102-104.

Pinassang, A. W., \& Rahardjo, S. T. (2017). Pengaruh Ekuitas Merek Terhadap Keputusan Pembelian Laptop Merek Toshiba Di Semarang. Diponegoro Journal of Management, 6(4), 123-134.

Rido, F., Fathor, A. S., \& Purnamawati, P. (2019). Pengaruh Ekuitas Merek Terhadap Keputusan Memilih Dengan Minat Sebagai Variabel Intervening. Competence: Journal of Management Studies, 13(1), 44-55.

Sari, R. R. (2017). Pengaruh Ekuitas Merek Melalui Kepercayaan Terhadap Aqua sebagai Variabel Intervening atau Perantara Terhadap Minat Beli Ulang Konsumen di Yogyakarta.

Suharyani, K., Nuridja, I. M., \& Haris, I. A. (2016). Pengaruh Ekuitas Merek Terhadap Keputusan Pembelian Produk Minuman Teh Botol Sosro Pada Mahasiswa Jurusan Pendidikan Ekonomi UNDIKSHA 2015. Jurnal Pendidikan Ekonomi Undiksha, 5(1).

Wiastuti, R. D., \& Kimberlee, S. (2018). Pengaruh Ekuitas Merek Terhadap Keputusan Pembelian di Simetri Coffee Roaster Puri, Jakarta. Jurnal Pariwisata, 5(2), 133-146.

Widhiarta, I. G. T. E., \& Wardana, M. (2015). Pengaruh Ekuitas Merek terhadap Keputusan Pembelian Iphone di Denpasar. E-Jurnal Manajemen Universitas Udayana, 4(4). 